\title{
Luteinizing hormone inhibits Fas-induced apoptosis in ovarian surface epithelial cell lines
}

\author{
K A Slot ${ }^{1}$, M de Boer-Brouwer ${ }^{1}$, M Houweling ${ }^{1}$, \\ A B Vaandrager ${ }^{1}$, J H Dorrington ${ }^{2}$ and $K$ J Teerds ${ }^{1,3}$ \\ ${ }^{1}$ Department of Biochemistry \& Cell Biology, Faculty of Veterinary Medicine, Utrecht University, Utrecht, The Netherlands \\ ${ }^{2}$ Banting \& Best Department of Medical Research, University of Toronto, Toronto, Canada \\ ${ }^{3}$ Human and Animal Physiology Group, Department of Animal Sciences, Wageningen University, Haarweg 10, 6709 PJ Wageningen, The Netherlands \\ (Requests for offprints should be addressed to K J Teerds; Email: katja.teerds@wur.nl)
}

\begin{abstract}
Gonadotrophins including LH have been suggested to play an important role in the etiology of epithelial ovarian cancers. The goal of the present study was to obtain more insight in the mechanism of gonadotrophin action on ovarian surface epithelium (OSE) cells. As the Fas system is known to be a major player in the regulation of the process of apoptosis in the ovary, we investigated whether LH interfered with Fas-induced apoptosis in the human OSE cancer cell lines HEY and Caov-3. Activation of Fas receptor by an agonistic anti-Fas receptor antibody induced apoptosis, as was evaluated by caspase-3 activation, poly(ADP-ribose) polymerase fragmentation, phosphatidylserine externalization and morphological changes characteristic of apoptosis. Co-treatment with $\mathrm{LH}$
\end{abstract}

reduced the number of apoptotic cells following activation of Fas in a transient manner, while LH by itself did not affect apoptosis or cell proliferation. The anti-apoptotic effect of LH could be mimicked by the membranepermeable cAMP analog 8-(4-chlorophenylthio)cAMP (8-CPT-cAMP), and blocked by H89, a specific inhibitor of protein kinase A (PKA). In conclusion, these findings suggest that LH protects HEY cells against Fas-induced apoptosis through a signaling cascade involving PKA. Although it is plausible that in vivo LH might also enhance OSE tumor growth through inhibition of apoptosis, further research is necessary to confirm this hypothesis.

Journal of Endocrinology (2006) 188, 227-239

\section{Introduction}

Although epithelial ovarian cancer is the most lethal of all gynecological cancers in women in the Western world, the etiology of this disease remains poorly understood (Auersperg et al. 2001). An inherited mutation in the BRCA1 gene and to a lesser extent in the BRCA2 gene has been implicated in 5-10\% of all cases (Ford et al. 1995). Another major risk factor for the development of epithelial ovarian cancer is related to the number of lifetime ovulations (Casagrande et al. 1979). The subsequent repeated rupture and repair of ovarian surface epithelium (OSE) at the ovulation site requires a high proliferative activity of the epithelium, resulting in an increased risk of mutations in these cells (Fathalla 1971). Moreover, OSE cells sequestered in crypts and inclusion cysts are exposed to high levels of stroma-derived growth factors and steroids, which might also contribute to ovarian cancer development (Cramer \& Welch 1983).

Evidence in support of hormonal involvement in ovarian carcinogenesis has been given by the observation that lower basal and peak gonadotrophin levels, as occurring in women during use of oral contraceptives, pregnancy and breastfeeding, were found to protect against ovarian cancer (Cramer et al. 1983, Whittemore et al. 1992). Conversely, the incidence of OSE cancer is increased in women during the years after menopause when serum gonadotrophin levels are high (Wu et al. 1988). Moreover, cases have been reported of OSE cancers arising in infertile women during or after prolonged treatment with gonadotrophins (Anderson \& Dimitrievich 1996, Kuroda et al. 1998). Considering the number of women receiving assisted reproductive treatment nowadays and the expected growing demand for ovulation induction during the coming years, it is of major importance to elucidate the role of gonadotrophins in the development and progression of epithelial ovarian cancer.

Until now, it is unclear whether gonadotrophins, like luteinizing hormone $(\mathrm{LH})$, act in an indirect endocrine manner (via stimulating steroid production in ovarian follicular cells) or directly target OSE cells. Expression of $\mathrm{LH}$ receptors (LH-Rs) has been demonstrated in normal OSE cells (Parrott et al. 2001a), in epithelial cells lining ovarian inclusion cysts (Kuroda et al. 1998) and 
in approximately $50 \%$ of ovarian carcinomas (Mandai et al. 1997). However, controversy exists as to whether there is a direct effect of LH on OSE cell survival, as increased (Casagrande et al. 1979, Simon et al. 1983, Osterholzer et al. 1985, Wimalasena et al. 1992, Syed et al. 2001, Parrott et al. 2001a), unchanged (Ala-Fossi et al. 1999, Ivarsson et al. 2001, Wright et al. 2002) as well as decreased (Zheng et al. 2000, Tourgeman et al. 2002) proliferation rates in response to $\mathrm{LH}$ have been reported. Many OSE tumors have been shown to contain low apoptotic indices and, therefore, it may be possible that LH influences OSE tumor growth and survival through inhibition of apoptosis. Indeed, it has been demonstrated that human chorionic gonadotrophin (hCG), an LH analog, suppressed apoptosis of ovarian granulosa cells (Chun et al. 1994). However, not much is known about the effects of LH on apoptosis in OSE cells.

A major pathway triggering apoptosis in OSE cells involves the Fas system (Ghahremani et al. 1998). Fas receptor (CD95) is a member of the tumor necrosis factor/nerve growth factor family which is expressed in many OSE cancers (Ben Hur et al. 1999, Das et al. 2000). Fas is activated by binding of Fas ligand, leading to activation of downstream death executioner factors, such as caspase-3, eventually resulting in cell death (Krammer 1999). Fas-induced apoptosis is also believed to be one of the mechanisms involved in cisplatin cytotoxity in OSE cancer cells (Uslu et al. 1996, Wakahara et al. 1997), a therapy often used as treatment for OSE cancer. We have examined the effect of LH on the occurrence of Fas-induced apoptosis in the human ovarian epithelial cancer cell lines HEY and Caov-3 and determined whether signaling occurs via protein kinase A (PKA) and/or protein kinase $\mathrm{C}$ (PKC) activation.

\section{Materials and Methods}

\section{Reagents}

All cell culture reagents were purchased from Gibco BRL, except for the medium, minimum essential medium without Phenol Red (M3149), which was obtained from Sigma. H89, an inhibitor of PKA, 8-(4-chlorophenylthio)cAMP (8-CPT-cAMP), H7, an inhibitor of PKC, 4- $\beta$-phorbol-12-myristate-13-acetate (PMA), an activator of PKC, 4- $\alpha$-phorbol-12-myristate-13-acetate, an inactive phorbolester, and 3-isobutyl-1-methylxanthine (IBMX), a phosphodiesterase inhibitor, were also purchased from Sigma. The agonistic mouse antihuman Fas IgM (clone CH11) was obtained from Upstate Biotechnology (Campro Scientific, Veenendaal, The Netherlands), the caspase inhibitor Z-VAD-FMK (benzyloxycarbonyl-Val-Ala-DL-Asp-fluoromethylketone) from the Promega Corporation, and ovine LH (NIH-LHS20) was a gift from NIDH (Bethesda, MD, USA). The antibody against the LH-R (P1B4) was a gift from
Dr J Wimalasena (University of Tennessee, Knoxville, TN, USA). This antibody was raised against purified rat LH-Rs, as described by Indrapichate and colleagues (1992) and has been shown to bind specifically to LH-Rs in different tissues (Bukovsky et al. 1993). Antibodies against Fas receptor (sc-715), Fas ligand (sc-956) and procaspase-3 (sc-1226) were purchased from Santa Cruz Biotechnology (SanverTech, Heerhugowaard, The Netherlands). The antibodies against poly(ADP-ribose) polymerase (PARP) p85 (G7341), active caspase-3 (AF835) and caspase-3 (A3537) were obtained from the Promega Corporation, R\&D Systems (ITK Diagnostics Uithoorn, The Netherlands) and DakoCytomation (Heverlee, The Netherlands), respectively. Secondary biotinylated goat anti-rabbit, rabbit anti-goat or goat anti-mouse IgGs were purchased from Vector Laboratories (Vectastain kit Elite; Burlingame, CA, USA) and horseradish peroxidase-conjugated goat anti-rabbit IgG was from Nordic Immunological Laboratories (Tilburg, The Netherlands). The bromodeoxyuridine (BrdU) incorporation assay detection kit and the annexin-V-Fluor staining kit were purchased from Roche Diagnostics, the cAMP Biotrak enzymeimmunoassay system was from Amersham Biosciences and the Supersignal chemiluminescence substrate kit (ECL) was from Pierce (Tattenhall, Cheshire, UK).

\section{Cell culture}

For this study, the human OSE cell lines HEY and Caov-3 were used. The HEY cell line was originally derived from a papillary cystadenocarcinoma (Jindal et al. 1995); while the Caov-3 was derived from an ovarian adenocarcinoma (American Type Culture Collection HTB-75; Manassas, VA, USA). Both cell lines were kindly provided by Dr D Lobb (McMasters University, Hamilton, Canada) and were routinely kept in culture at $37^{\circ} \mathrm{C}$ in a $5 \% \mathrm{CO}_{2}$ incubator in Eagle's minimal essential medium without Phenol Red. The culture medium was supplemented with $0 \cdot 1 \mathrm{mM}$ non-essential amino acids, $2 \mathrm{mM}$ glutamine, $50 \mathrm{U} / \mathrm{ml}$ penicillin/streptomycin, $1.5 \mathrm{mM}$ Hepes and 10\% heat-inactivated fetal calf serum. The cells were sub-cultured twice a week and only those cells in the exponential growth phase were used in the experiments described.

\section{Immunohistochemistry}

To detect the LH-R, Fas receptor (Fas), Fas ligand, procaspase- 3 , active caspase- 3 and fragmented PARP in OSE cancer cell lines, cells were grown on glass coverslips placed in 24-multiwell culture dishes and seeded at a density of $2.5 \times 10^{4}$ cells/well. After incubation overnight the culture medium was replaced by serum-free medium and cells were cultured for another $24 \mathrm{~h}$. Then the cells were fixed for $15 \mathrm{~min}$ in $4 \%$ buffered formalin, $\mathrm{pH} 7 \cdot 4$, 
and immunohistochemistry was performed as been described previously (Teerds \& Dorrington 1995). Briefly, cells were washed in $0 \cdot 01 \mathrm{M}$ Tris-buffered saline (TBS; $\mathrm{pH} 7 \cdot 4$ ), and incubated with $0 \cdot 1 \mathrm{M}$ glycine in TBS for $30 \mathrm{~min}$. After rinsing, cells were permeabilized with $0 \cdot 1 \%$ Triton X-100 in TBS for $5 \mathrm{~min}$. Cells were, depending on the species in which the secondary antibody was raised, blocked for $30 \mathrm{~min}$ with 10\% normal rabbit, goat or mouse serum in TBS, and then incubated overnight at $4{ }^{\circ} \mathrm{C}$ with rabbit anti-human polycloncal antibodies against Fas, Fas ligand (dilution 1:100), active caspase-3 $(0.5 \mu \mathrm{g} / \mathrm{ml})$ or PARP p85 (dilution 1:100), with a goat anti-human polyclonal antibody against procaspase-3 (dilution 1:100) or with a mouse anti-rat monoclonal antibody against LH-R (dilution 1:3000). All antibodies were diluted in TBS containing $0.05 \%$ acetylated BSA (Aurion, Wageningen, The Netherlands). After washing the cells in TBS, the cells were incubated with the corresponding biotinylated goat anti-rabbit (Fas, Fas ligand, active caspase-3 and PARP p85), rabbit anti-goat (procaspase-3) or goat anti-mouse (LH-R) antibodies diluted 1:200 in TBS containing 0.05\% acetylated BSA for $60 \mathrm{~min}$. Cells were again washed in TBS and subsequently incubated for at least $60 \mathrm{~min}$ with the components avidin (A) and biotin (B) of the $\mathrm{ABC}$ staining kit Elite. Both components $(\mathrm{A}$ and $\mathrm{B})$ were diluted 1:1000 and prepared at least $15 \mathrm{~min}$ before use. Then, cells were washed in TBS, and bound antibody was visualized after the addition of a $0.6 \mathrm{mg} / \mathrm{ml}$ solution of 3,3'-diaminobenzidine tetrachloride (Sigma) in TBS to which $0.03 \% \mathrm{H}_{2} \mathrm{O}_{2}$ was added. Finally, the cells were counterstained with Mayer's hematoxylin. Controls, in which the primary antibody was replaced by normal rabbit, goat or mouse serum respectively, were processed similarly. No staining was observed in these controls.

\section{Western blot analysis}

Cells seeded at an initial density of $2.5 \times 10^{5}$ cells/dish in $20 \mathrm{~cm}^{2}$ culture dishes were incubated overnight in culture medium. Next, the culture medium was replaced by serum-free culture medium supplemented with or without agonistic anti-Fas antibody $(50 \mathrm{ng} / \mathrm{ml} \mathrm{CH11)}$ and a caspase inhibitor, Z-VAD-FMK $\left(10^{-5} \mathrm{M}\right)$, and incubated for 4,8 or $24 \mathrm{~h}$. Culture medium was collected and centrifuged for $5 \mathrm{~min}$ at $6000 \mathrm{~g}$ to spin down the detached cells. Adherent cells were scraped from the surface following the addition of SDS sample buffer. Both cellular samples were pooled together in SDS sample buffer separated by $12 \%$ SDS/PAGE $\left(1 \times 10^{4}\right.$ cells/lane $)$ and then transferred onto nitrocellulose membranes. The membranes were blocked with $5 \%$ non-fat dry milk in TTBS $(10 \mathrm{mM}$ Tris, pH 7.5, $100 \mathrm{mM} \mathrm{NaCl}$ and $0 \cdot 1 \%$ Tween-20) for $1 \mathrm{~h}$, and incubated overnight at $4{ }^{\circ} \mathrm{C}$ with a rabbit anti-human polyclonal antibody against Fas, Fas ligand and caspase- 3 (which reacts with both the $32 \mathrm{kDa}$ proenzyme and the spliced $20 \mathrm{kDa}$ active form of caspase3), with a goat anti-human polyclonal antibody against procaspase-3, diluted 1:500 in blocking buffer, or with blocking buffer only (negative control). After washing three times with TTBS, the membranes were incubated for $1 \mathrm{~h}$ with horseradish peroxidase-conjugated goat antirabbit IgG (Fas, Fas ligand, caspase-3) diluted 1:10 000 or rabbit anti-goat (procaspase-3) diluted 1:5000 in blocking buffer. The presence of antibody-protein complexes was detected by enhanced chemiluminescence. A human fibroblast lysate in SDS/PAGE buffer (Becton Dickonson, Franklin Lakes, NJ, USA) was used as a positive control and bands were detected at the appropriate sizes. In the absence of the primary antibodies no specific bands were detected on the blot.

\section{Cell death analysis}

Apoptotic cells were identified by analysis of phosphatidylserine (PS) at the outer leaflet of apoptotic cell membranes using annexin- $\mathrm{V}$ and propidium iodide (Vermes et al. 1995). Cells were seeded at a density of $2.5 \times 10^{4}$ cells/well in 24-multiwell culture dishes and cultured overnight, followed by treatment in serumfree culture medium supplemented with or without an agonistic mouse anti-human Fas IgM $(50 \mathrm{ng} / \mathrm{ml}$ clone $\mathrm{CH} 11)$ at various times in the absence or presence of the following compounds: Z-VAD-FMK $\left(10^{-5} \mathrm{M}\right)$, LH $(0 \cdot 1,1$ or $10 \mathrm{ng} / \mathrm{ml}), 8-C P T-c A M P\left(10^{-6} \mathrm{M}\right)$, H89 $\left(10^{-6} \mathrm{M}\right)$, PMA $\left(10^{-6} \mathrm{M}\right)$, inactive phorbolester $\left(10^{-6} \mathrm{M}\right)$ or H7 $\left(10^{-6} \mathrm{M}\right)$. Detached cells were retained by centrifugation of the culture medium for $5 \mathrm{~min}$ at $6000 \mathrm{~g}$ and adhesive cells were harvested after $5 \mathrm{~min}$ of trypsinization. Adhesive and floating cells were pooled together and were incubated with annexin-V-fluorescein (dilution 1:200) containing propidium iodide (dilution 1:500) in Hepes buffer for $10 \mathrm{~min}$ in the dark. The percentage of annexin-V-labeled cells was measured per 7500 cells and quantified by flow cytometry, using a FACScan flow cytometer (Becton Dickinson).

\section{Cell growth analysis}

The dose-response effect of LH and 8-CPT-cAMP on the proliferative activity of the ovarian cancer cell lines was assessed by a BrdU incorporation assay using a 5-bromo2 -deoxy-uridine labeling and detection kit. BrdU is an analog of thymidine that is incorporated into the DNA of cells in the $\mathrm{S}$ phase of the cell cycle. Cells, seeded at a density of $2.5 \times 10^{4}$ cells/well, were grown on glass coverslips placed in 24-multiwell culture dishes in culture medium. After culture overnight the medium was discarded and replaced by serum-free culture medium with or without supplementation of LH $(0 \cdot 1,1$ or $10 \mathrm{ng} / \mathrm{ml})$ or $10^{-6} \mathrm{M} 8$-CPT-cAMP, followed by another culture period of 8 or $24 \mathrm{~h}$. Three hours prior to the end of each 
culture period, $\mathrm{BrdU}$ was added to the culture medium in a final concentration of $3 \mu \mathrm{g} / \mathrm{ml}$. Cells were fixed in methacarn (60\% methanol, 30\% chloroform and 10\% acetic acid) for $10 \mathrm{~min}$ at room temperature. After fixation the cells were rinsed with $70 \%$ ethanol, PBS and finally distilled water. The cells were pretreated with $1 \%$ periodic acid at $55 \mathrm{C}$ for $20 \mathrm{~min}$, followed by immersion in respectively tap water and PBS. Next, the cells were blocked for $10 \mathrm{~min}$ with 5\% BSA diluted in PBS and then incubated for $1 \mathrm{~h}$ with a mouse anti-BrdU antibody diluted 1:100 in PBS containing 0.05\% acetylated BSA. The coverslips were again washed in PBS and incubated for $1 \mathrm{~h}$ with a goat anti-mouse $\operatorname{IgG}$ horseradish peroxidase-labeled antibody diluted 1:100 in PBS containing $0.05 \%$ acetylated BSA. After this incubation the cells were washed in PBS and bound antibody was visualized after the addition of a $0.6 \mathrm{mg} / \mathrm{ml}$ solution of 3, $3^{\prime}$-diaminobenzidine tetrachloride in PBS to which $1 \%$ nickel aminosulphate and $0 \cdot 05 \% \mathrm{H}_{2} \mathrm{O}_{2}$ were added. The cells were subsequently counterstained with Mayer's hematoxylin. Black staining identified BrdU incorporation into the nuclei.

To examine the specificity of the immunostaining, control coverslips were incubated with normal mouse serum instead of primary antibody and similarly processed. No staining was observed in these controls. HEY cells cultured in the presence of serum were used as a positive control and processed as described above. The percentage of BrdU-labeled cells was determined by counting 500 (labeled and unlabeled) cells per coverslip under a light microscope. Values are presented as means \pm S.E.M. from one representative experiment using quadruplicates. Experiments were repeated three times with similar results.

\section{cAMP enzyme-immunoassay}

To measure total cAMP levels (intracellular and secreted in the medium), cells $\left(2.5 \times 10^{4}\right.$ cells/well $)$ were plated in 24-multiwell dishes and grown overnight in culture medium. The medium was discarded and cells were pre-incubated in serum-free culture medium for $1 \mathrm{~h}$ and then treated with LH $(0 \cdot 1$ and $10 \mathrm{ng} / \mathrm{ml})$ for $60 \mathrm{~min}$ in the presence of $1 \mathrm{mM}$ IBMX. Incubations without IBMX were below the detection level of the assay used. Therefore, all cAMP measurements were performed in the presence of IBMX, which resulted in a significant increase in basal cAMP levels, making a stimulus detectable. Treatment with IBMX (1 mM) alone was used as a control. Total cAMP levels (present in both the medium and within the cells) were measured using a cAMP Biotrak ${ }^{\circledR}$ competitive enzyme-immunoassay (EIA) system (GE Healthcare, Eindhoven, The Netherlands), according to the manufacturer's protocol.

\section{Statistical analysis}

Statistics was performed by a one-way analysis of variance (ANOVA), unless otherwise mentioned. Differences between group variances were determined with Tukey's multiple comparison test. Values were considered to be statistically significantly different when $P<0 \cdot 05$.

\section{Results}

Presence of Fas, Fas ligand and procaspase-3 in HEY cells

To investigate whether LH affects Fas-induced apoptosis in OSE cells, we first demonstrated the presence of the Fas pathway in HEY cells. Fas receptor and signaling molecules were detected by both Western blot analysis and immunohistochemistry. In HEY cells Fas receptor $(45 \mathrm{kDa})$, Fas ligand $(40 \mathrm{kDa})$ and procaspase-3 (32 kDa) proteins were observed to be present under basal conditions (Fig. 1). Fas immunostaining resulted in staining of an additional protein band of approximately $40 \mathrm{kDa}$, which has also been reported by Kamitani et al. (1997).

\section{Activation of Fas induces apoptosis in HEY cells}

To determine whether the presence of Fas, Fas ligand and procaspase- 3 in HEY cells was accompanied by a functional Fas pathway, cells were treated with an agonistic anti-Fas receptor antibody (CH11). Significant apoptosis occurred in HEY cells upon CH11 treatment. Dramatic changes in cell morphology, characteristic for apoptosis, were observed in response to treatment with $50 \mathrm{ng} / \mathrm{ml}$ CH11 (Fig. 2A). Cells shrank, rounded up, showed blebbing in quick succession, and detached from the culture dish in a time- and concentration-dependent manner (data not shown). In addition, Fas receptor activation also resulted in splicing of procaspase- 3 and the immunocytochemical detection of active caspase- 3 and PARP cleavage fragments (Fig. 2A), indicating that CH11 induced apoptosis in these cells. Caspase-3 activation was further confirmed by Western blot analysis (Fig. 2B). This stimulatory effect on caspase-3 activity was completely reversed by co-treatment with Z-VAD-FMK, a wellknown inhibitor of caspase-3 processing (Fig. 2B). Fasinduced apoptosis resulted in a significant translocation of PS to the outer leaflet of the plasma membrane as quantified by FACS analysis using annexin-V/propidium iodide double staining (Fig. 2C). The number of cells displaying PS at the outer leaflet of the plasma membranes increased over time with $12.1 \pm 2 \cdot 4,18.3 \pm 2.7$ and $44 \cdot 1 \pm 4 \cdot 2 \%$ of HEY cells staining positive for annexin following 6,12 and $24 \mathrm{~h}$ of $\mathrm{CH} 11$ treatment, respectively (Fig. 2D). Viable cells that lacked annexin staining remained in culture even after $72 \mathrm{~h}$, indicating that not all HEY cells became apoptotic during $\mathrm{CH} 11$ treatment (data not shown). Z-VAD-FMK administration significantly 


\section{A}

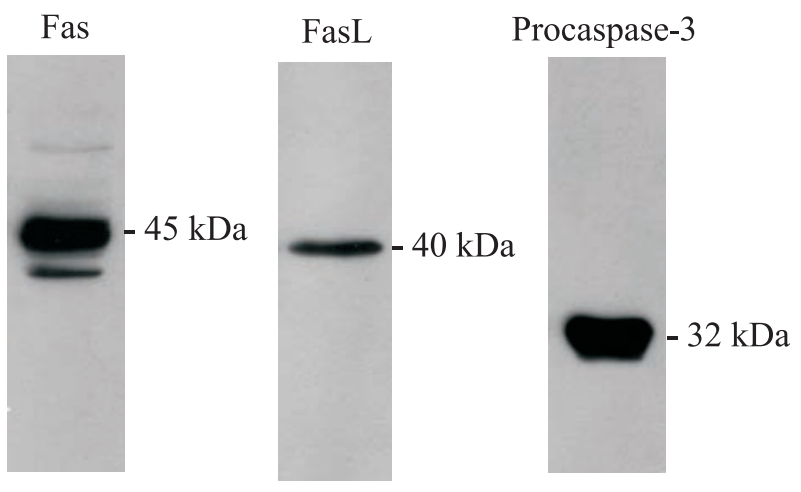

B

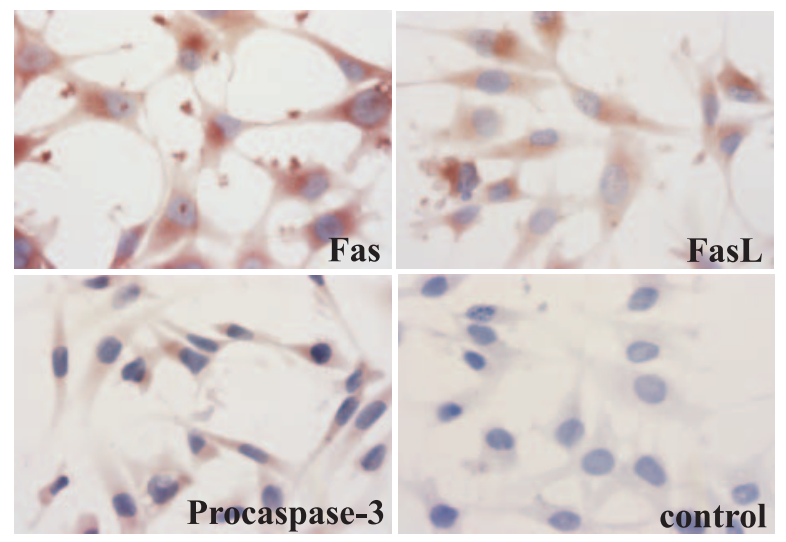

Figure 1 Detection of Fas, Fas ligand and procaspase-3 protein in HEY cells. HEY cells $\left(5 \times 10^{4}\right.$ cells $\left./ \mathrm{ml}\right)$ were maintained overnight and subsequently serum and growth factor starved for $24 \mathrm{~h}$. Fas, Fas ligand (FasL) and procaspase-3 protein levels were estimated by Western blotting (A) and immunohistochemistry (B) as described in the Materials and Methods section. Immunopositive cells showed brown-stained cytoplasm. The control represents a staining in which the polyclonal primary antibody was replaced by normal rabbit serum. A representative experiment is shown, which was repeated three times with similar results.

inhibited Fas-induced PS externalization within the time frame studied to similar levels $(P<0 \cdot 01)$, as observed in controls (Fig. 2C-D).

\section{Presence of $L H-R$ and $L H$ responsiveness in $H E Y$ cells}

Under basal culture conditions LH-R protein could be detected in HEY cells. LH-R immunostaining was detected intracellularly and on the plasma membrane of HEY cells (Fig. 3A). To test whether the LH-R was responsive to $\mathrm{LH}$ in these cells, HEY cells were treated without or with $\mathrm{LH}(0 \cdot 1$ and $10 \mathrm{ng} / \mathrm{ml})$ in the presence of IBMX (1 mM), a phosphodiesterase inhibitor, and total cAMP levels were measured. Treatment with $0 \cdot 1$ and $10 \mathrm{ng} / \mathrm{ml} \mathrm{LH}$ resulted respectively in a $1 \cdot 3$ - and $1 \cdot 4$-fold increase in total cAMP levels compared with the IBMX control after $60 \mathrm{~min}$ of incubation (Fig. 3B).

LH promotes cell survival by suppressing Fas-induced apoptosis in HEY cells

Treatment of HEY cell cultures with LH resulted in a significant inhibition of CH11-induced apoptosis in a concentration-dependent manner as measured by FACS analysis, using annexin- $\mathrm{V} /$ propidium iodide double staining. A representative experiment is shown in Fig. 4A. When treated with low doses of LH $(0 \cdot 1$ or $1 \mathrm{ng} / \mathrm{ml})$ for $12 \mathrm{~h}$, the percentage of apoptotic cells was significantly reduced by respectively $22 \cdot 7 \pm 5 \cdot 3(n=7)$ and $29 \cdot 2 \pm$ $3 \cdot 1 \%(n=11)$ compared with cells treated with CH11 alone (Fig. 4B). Z-VAD-FMK inhibited Fas-induced apoptosis (for a representative experiment see Fig. 2D). Treatment with a higher dose $(10 \mathrm{ng} / \mathrm{ml})$ had no modulating effect on apoptosis in HEY cells. The anti-apoptotic effect of $\mathrm{LH}$ observed at $12 \mathrm{~h}$ of culture was transient, as after $24 \mathrm{~h}$ of incubation the amount of Fas-induced apoptosis was similar to cells cultured in the absence of LH (Fig. 4A). A similar trend was observed when apoptosis was determined by flow cytometry by measuring DNA content in permeabilized cells (data not shown) as described by Guthrie et al. (1998). The level of apoptosis was somewhat lower with this assay compared with the annexin- $\mathrm{V}$ assay. This was not unexpected as DNA fragmentation is a late apoptotic event and the detection of PS at the outer plasma membrane leaflet by annexin-V is a relatively early apoptotic marker.

LH does not promote OSE cell survival by cell proliferation in HEY cells

To exclude the possibility that the anti-apoptotic effect of LH was actually caused by increased cell growth, we measured incorporation of BrdU by HEY cells in the absence of serum. HEY cells proliferated under these serum-free culture conditions. The number of cells that incorporated $\mathrm{BrdU}$ decreased over time with $28 \cdot 7 \pm 0 \cdot 8$ and $7 \cdot 8 \pm 1 \cdot 2 \%$ of HEY cells staining positive for BrdU following 8 and $24 \mathrm{~h}$ of culture, respectively $(n=3)$. LH did not change the levels of $\mathrm{BrdU}$ incorporation in HEY cells. After $8 \mathrm{~h}$ of incubation, the percentage of BrdU-labeled cells in $0 \cdot 1,1$ and $10 \mathrm{ng} / \mathrm{ml} \mathrm{LH-treated}$ HEY cells was $29 \cdot 2 \pm 0 \cdot 9,29 \cdot 3 \pm 1 \cdot 3$ and $29 \cdot 3 \pm 1 \cdot 3 \%$, respectively, versus $8 \cdot 1 \pm 0 \cdot 8,8 \cdot 2 \pm 1 \cdot 1$ and $8 \cdot 3 \pm 1 \cdot 1 \%$ following $24 \mathrm{~h}$ of culture.

\section{LH also suppresses Fas-induced apoptosis in Caov-3 cells}

To test whether the suppressive effect of LH on Fasinduced apoptosis in HEY cells was not a cell-line-specific effect; we also assessed the presence, activation and modulation of the Fas pathway in Caov-3 cells. Fas receptor, 
A
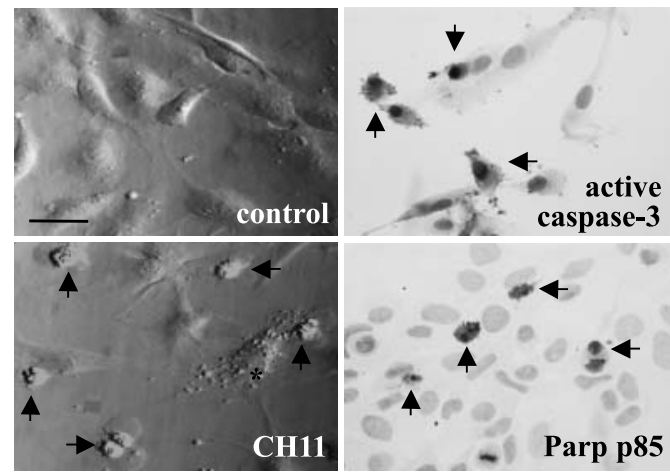

B

\begin{tabular}{r|ccc|ccc|ccc|} 
& \multicolumn{10}{|c|}{ treatment period (h) } \\
& 4 & 8 & 24 & 4 & 8 & 24 & 4 & 8 & 24 \\
\hline CH11 & - & - & - & + & + & + & + & + & + \\
Zvadfmk & - & - & - & - & - & - & + & + & +
\end{tabular}

$32 \mathrm{kDa}-$

$20 \mathrm{kDa} \rightarrow$

C

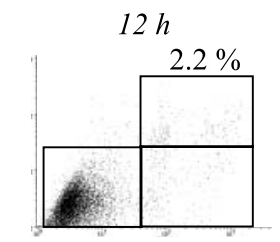

$24 h$



$6 h$

$2.6 \%$
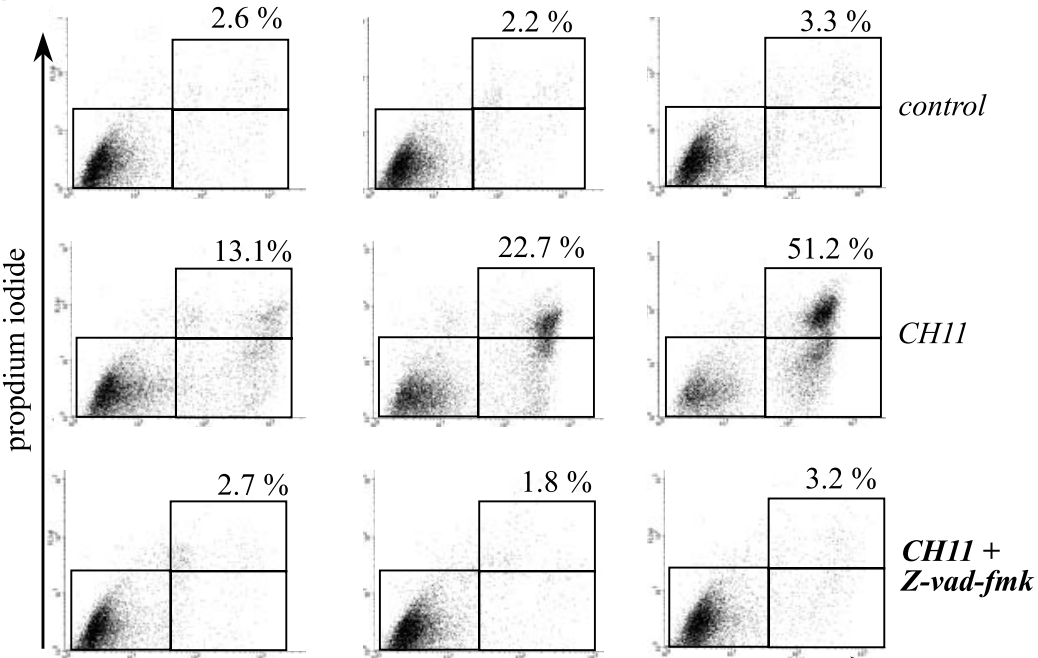

Annexin-V

D

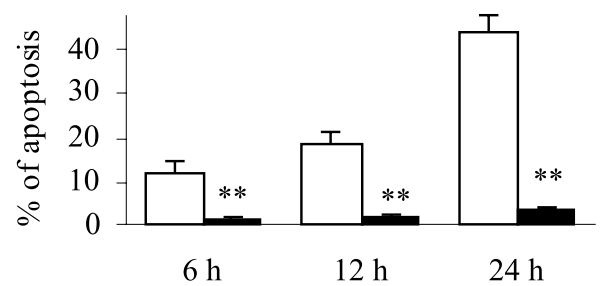


A

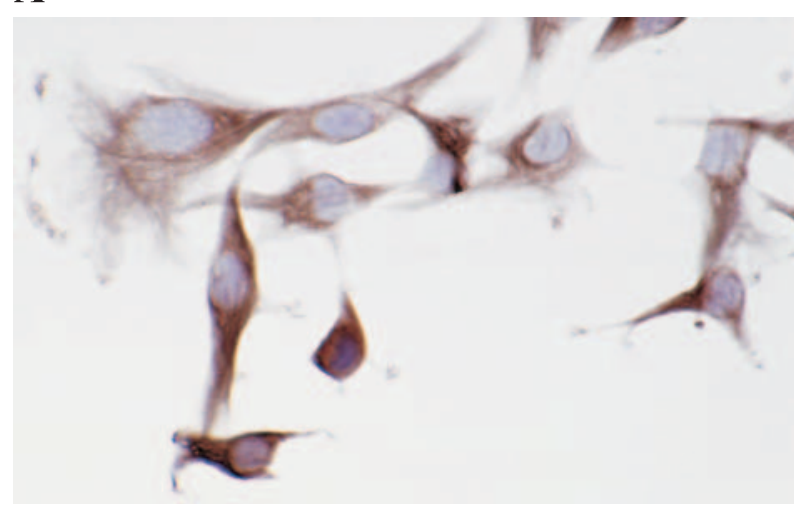

B

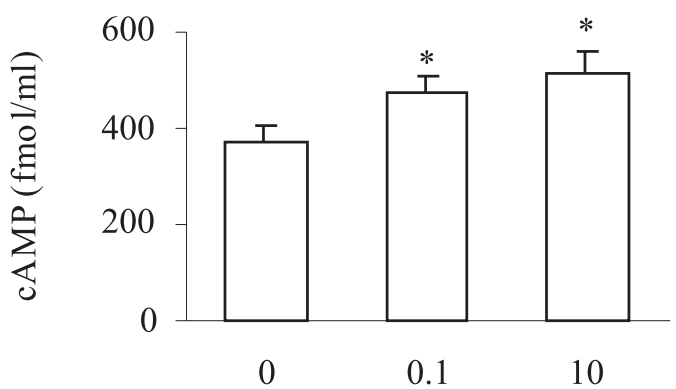

Figure 3 Presence of functional LH-Rs in HEY cells. (A) HEY cells $\left(5 \times 10^{4}\right.$ cells $\left./ \mathrm{ml}\right)$ were maintained overnight, then serum-starved for $24 \mathrm{~h}$ and $\mathrm{LH}-\mathrm{R}$ protein expression was determined by immunohistochemistry as described in the Materials and Methods section. The cytoplasm of cells stained positively with the LH-R antibody was brown. (B) HEY cells were incubated in serum-free medium for $1 \mathrm{~h}$ and then further cultured in the absence $(0 \mathrm{ng} / \mathrm{ml}$ $\mathrm{LH})$ or presence $(0 \cdot 1$ or $10 \mathrm{ng} / \mathrm{ml})$ of $\mathrm{LH}$ and $1 \mathrm{mM} \mathrm{IBMX}$ for $60 \mathrm{~min}$. Total cAMP levels (intracellular and secreted in the medium) were measured as described in the Materials and Methods section. Values are expressed as means \pm S.E.M. of quadruplicate incubations from one representative experiment. The experiment was repeated twice. A Student's $t$-test was used to compare the mean of cAMP levels between the control group and the groups treated with $\mathrm{LH}$. Significantly different from control $(\mathrm{IBMX}+0 \mathrm{ng} / \mathrm{ml} \mathrm{LH}),{ }^{*} P<0 \cdot 05$.
Fas ligand and procaspase- 3 were present in Caov-3 cells under basal conditions as detected by both Western blot analysis and immunocytochemistry (Fig. 5A and B). The Caov-3 cell line was also responsive to Fas activation although the degree of Fas-induced cell death varied. The level of Caov-3 cells that stained positive for annexin-V following $12 \mathrm{~h}$ of $\mathrm{CH} 11$ administration was 2-fold lower compared with HEY cells (compare Fig. 5C with Fig. 4B). Despite differences in the number of apoptotic cells between the two ovarian cancer cell lines, the transient anti-apoptotic effect of LH was very similar in both cell lines. However, due to the relative resistance of Caov-3 cells to CH11 within the studied time frame, we decided to carry out the remainder of the experiments in HEY cells only.

The anti-apoptotic effect of $\mathrm{LH}$ on Fas-induced apoptosis was mimicked by PKA activation and reversed by blocking of $P K A$ activity in HEY cells

In steroid-producing ovarian follicular cells, the binding of LH to its cognate receptor stimulates adenylate cyclase, resulting in subsequent production of cAMP and activation of PKA (Hunzicker-Dunn \& Birnbaumer 1985, Cooke 1999). To investigate whether the LH antiapoptotic pathway in OSE cancer cells includes cAMP/ PKA, we tested whether addition of a cell-membranepermeable cAMP analog (8-CPT-cAMP) mimicked the anti-apoptotic effect of LH in HEY cells. Addition of $10^{-6} \mathrm{M} 8$ 8-CPT-cAMP has been demonstrated in other cell-culture systems to mimic the effects of $\mathrm{LH}$ on steroidgenesis (Cooke 1999).

Figure 6 shows the effects of an activator and inhibitor of PKA activity on Fas-induced apoptosis in HEY cells. The percentage of Fas-induced apoptotic cells was reduced significantly by $37 \cdot 0 \pm 2 \cdot 0 \%(P<0 \cdot 01)$ following $8 \mathrm{~h}$ treatment with 8 -CPT-cAMP $\left(10^{-6} \mathrm{M}\right)$. This reduction was similar to what was observed after treatment with $1 \mathrm{ng} / \mathrm{ml} \mathrm{LH} \mathrm{(42 \cdot 1} \mathrm{\pm} \mathrm{3.7 \% ;} \mathrm{Fig.} \mathrm{6).} \mathrm{No} \mathrm{significant} \mathrm{additive}$ effects on the inhibition of Fas-induced apoptosis were observed after combined treatment of $10^{-6} \mathrm{M}$ 8-CPTcAMP and $1 \mathrm{ng} / \mathrm{ml} \mathrm{LH}$, compared with single LH or 8-CPT-cAMP treatment. The anti-apoptotic effect of 8-CPT-cAMP was not due to increased cell growth,

Figure 2 Effect of Fas stimulation on various parameters indicative for apoptosis in HEY cells. (A) HEY cells $\left(5 \times 10^{4}\right.$ cells $\left./ \mathrm{ml}\right)$ were maintained overnight and then treated for $8 \mathrm{~h}$ without or with an agonistic anti-Fas antibody (50 ng/ml CH11) in serum-free medium. The left of panel A shows phase-contrast images of non-stimulated (control) and $\mathrm{CH} 11$-stimulated HEY cells. The right panel shows immunohistochemical staining for active caspase-3 and PARP p85 in $\mathrm{CH} 11$-treated HEY cells. Arrows indicate apoptotic cells. (B) HEY cells were treated without or with $50 \mathrm{ng} / \mathrm{ml} \mathrm{CH} 11$ in the presence or absence of $10^{-5} \mathrm{M}$ Z-VAD-FMK for 4,8 and $24 \mathrm{~h}$. The presence of procaspase-3 $(32 \mathrm{kDa})$ and active caspase-3 $(20 \mathrm{kDa})$ was determined in whole cell lysates as described in the Materials and Methods section. (C) PS exposure was determined by FACS analysis at various times after treating cells without additions (control), $50 \mathrm{ng} / \mathrm{ml} \mathrm{CH} 11$ or $50 \mathrm{ng} / \mathrm{ml} \mathrm{CH} 11$ plus $10^{-5} \mathrm{M}$ Z-VAD-FMK as described in the Materials and Methods section. Values on top of the right quadrant are the sum of the relative number of cells positive for annexin-V. Data shown are from one representative experiment, which was repeated three times with similar results. (D) Quantification of Fas-induced apoptosis in HEY cells following treatment with $50 \mathrm{ng} / \mathrm{ml} \mathrm{CH11} \mathrm{in} \mathrm{the}$ absence (open bars) or presence of $10^{-5} \mathrm{M}$ Z-VAD-FMK (closed bars) as described for panel C. Values shown are means \pm s.E.M. from four independent experiments. Significantly different from $\mathrm{CH} 11$-treated cells, ${ }^{* *} P<0 \cdot 01$. 
A
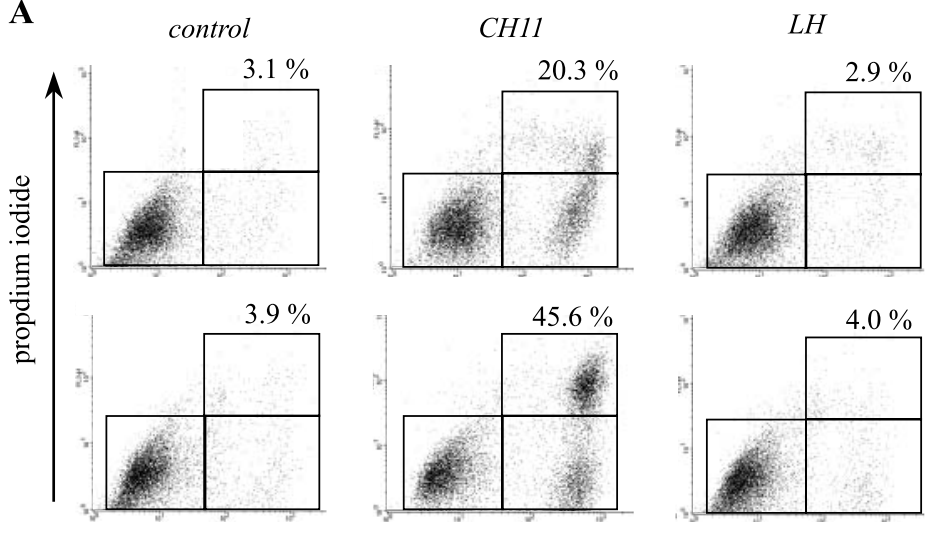

LH

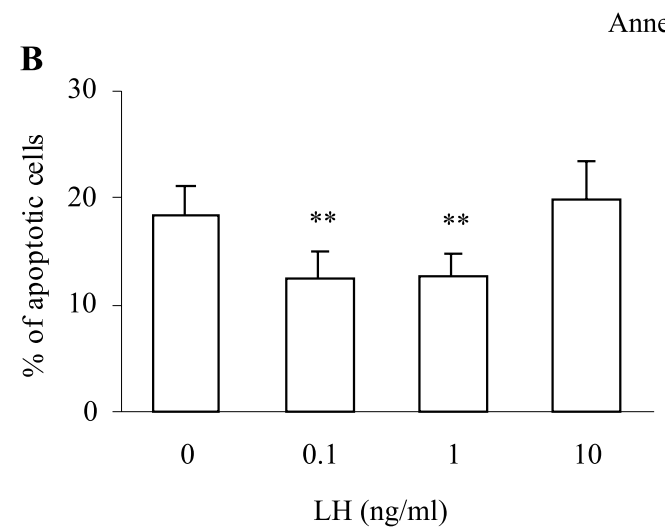

Figure 4 Effect of LH on Fas-induced apoptosis in HEY cells. (A) FACS analysis of apoptosis in HEY cells after incubation in serum-free medium in the absence (control) or presence of $1 \mathrm{ng} / \mathrm{ml} \mathrm{LH}$ and/or $50 \mathrm{ng} / \mathrm{ml}$ $\mathrm{CH} 11$ for 12 and $24 \mathrm{~h}$. Values on top of the right quadrant are the sum of the relative number of cells positive for annexin-V. Data shown are from a representative experiment. (B) Quantification of Fas-induced apoptosis in HEY cells $12 \mathrm{~h}$ after treatment with various concentrations of $\mathrm{LH}$ as shown. Apoptotic indices represent the percentage of positively labeled annexin- $\mathrm{V}$ cells minus its respective non-treated control, which were determined as described for panel A. Values shown are means \pm S.E.M. from eight independent experiments. Significantly different from $\mathrm{CH} 11$-treated cells, ${ }^{* *} \mathrm{P}<0 \cdot 01$.

as no significant differences were observed in the percentage of BrdU-labeled HEY cells in the absence or presence of $10^{-6} \mathrm{M} 8$-CPT-cAMP (respectively $28 \cdot 7 \pm 0 \cdot 8$ and $30 \cdot 7 \pm 0 \cdot 9 \%$ ). The effect of the cAMP analog was, however, biphasic. In contrast to the inhibitory dose of $10^{-6} \mathrm{M} 8$ 8-CPT-cAMP, no effect was observed in HEY cells treated with $10^{-5} \mathrm{M} 8$-CPT-cAMP while a high dose of 8-CPT-cAMP $\left(10^{-4} \mathrm{M}\right)$ significantly enhanced Fas-induced apoptosis by approximately $40 \%$. High doses of cAMP analogs have been shown before to induce or accelerate apoptosis in various human cancer cell lines (Kim et al. 2001). Moreover, BrdU incorporation was also significantly increased in HEY cells treated with $10^{-4} \mathrm{M} 8$-CPT-cAMP $(34 \cdot 7 \pm 1 \cdot 2$ versus $28 \cdot 7 \pm 0 \cdot 8 \%$ in non-treated cells $(P<0 \cdot 05))$, suggesting an enhanced cell turnover in the presence of high concentrations of cAMP analogs.
Furthermore, we have investigated whether an inhibitor of PKA activity (H89) could antagonize the antiapoptotic effect of LH in HEY cells (Fig. 6). H89 by itself did not affect the level of apoptosis (data not shown), but the anti-apoptotic effect of LH (Fig. 6) and of $10^{-6} \mathrm{M}$ 8-CPT-cAMP (data not shown) on Fas-induced apoptosis was almost completely reversed when $10^{-6} \mathrm{M}$ H89 was added to the culture medium.

To investigate the possibility whether $\mathrm{LH}$ also signals via PKC, HEY cells were treated with an activator and inhibitor of PKC activity (Fig. 6). In the presence of the phorbolester PMA $\left(10^{-6} \mathrm{M}\right)$, a stimulator of PKC activity, the number of Fas-induced apoptotic cells was significantly reduced compared with untreated Fasstimulated cells, while no significant additive effect on the inhibition of Fas-induced apoptosis was observed after combined treatment with LH and PMA. Treatment with 
A

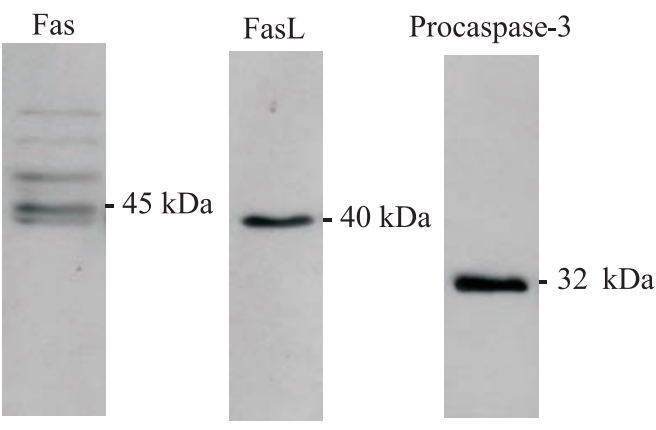

C

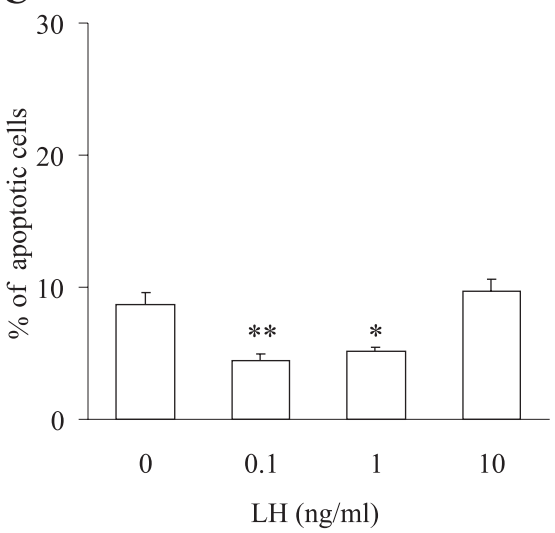

B

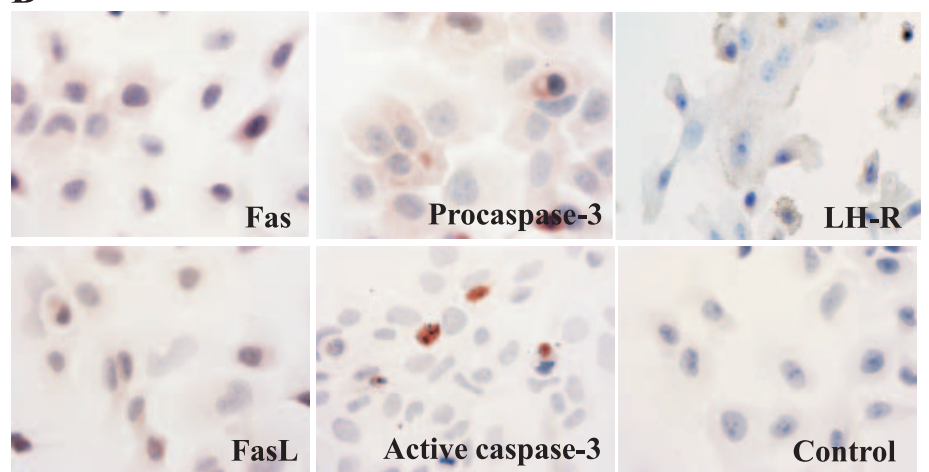

Figure 5 Presence, activation and modulation of the Fas pathway in Caov- 3 cells. Caov- 3 cells $\left(5 \times 10^{4}\right.$ cells $\left./ \mathrm{ml}\right)$ were maintained overnight and subsequently serum and growth factor starved for $24 \mathrm{~h}$. Fas, Fas ligand (FasL) and procaspase-3 protein levels were estimated by Western blotting (A) and immunohistochemistry (B) as described in the Materials and Methods section. Immunopositive cells showed a brown cytoplasm. The control represents a staining in which the primary polyclonal antibody was replaced by normal rabbit serum. A representative experiment is shown, which was repeated three times with similar results. (C) PS exposure was determined by FACS analysis after treating cells with $50 \mathrm{ng} / \mathrm{ml} \mathrm{CH11} \mathrm{in} \mathrm{the} \mathrm{absence} \mathrm{or} \mathrm{presence} \mathrm{of} \mathrm{various} \mathrm{concentrations} \mathrm{of} \mathrm{LH}$ as shown for $12 \mathrm{~h}$ as described in the legend of Fig. 4. Significantly different from CH11-treated cells, ${ }^{* *} P<0 \cdot 01$ or ${ }^{*} P<0 \cdot 05$.

an inactive phorbolester $\left(10^{-6} \mathrm{M}\right)$ in either the absence or presence of LH did not affect the number of Fasinduced apoptotic cells. Additionally, treatment with $\mathrm{H} 7$ $\left(10^{-6} \mathrm{M}\right)$, an inhibitor of PKC activity, by itself did not affect the level of apoptosis (data not shown). H7 only partially prevented the anti-apoptotic effect of LH in HEY cells (Fig. 6). Moreover, no significant differences were observed between CH11-stimulated HEY cells treated with LH in the absence or presence of H7. Thus, the anti-apoptotic effect of LH on CH11-induced apoptosis was mimicked by PKC activation, but not completely reversed by blockade of PKC activity. Although the involvement of PKC cannot be completely excluded, our observations suggest that $\mathrm{LH}$ exerts its anti-apoptotic effect predominantly through activation of the cAMP/ PKA system.

\section{Discussion}

The results of the present study suggest a direct effect of LH on the survival of the OSE cancer cell lines HEY and Caov-3 following Fas-receptor activation. OSE cells expressed both functional $\mathrm{LH}$ and Fas receptors; addition of LH resulted in cAMP production, suggesting that the LH-R is functional, while stimulation of the Fas receptor induced apoptosis in these cells. LH did not affect cell proliferation in the absence of serum and growth factors, but affected OSE cell survival through the inhibition of Fas-induced apoptosis. This anti-apoptotic effect of LH could be mimicked by a membrane-permeable cAMP analog (8-CPT-cAMP), while treatment with a PKA inhibitor (H89) reversed the anti-apoptotic effect of $\mathrm{LH}$. These observations suggest that LH exerts its antiapoptotic effect predominantly through activation of PKA.

The Fas system has been shown to play a major role in regulating ovarian homeostasis by triggering apoptosis in various ovarian cell types, such as granulosa and theca cells (Tilly 1996, Ghahremani et al. 1998, Foghi et al. 1998). A role for Fas-induced apoptosis has also been implicated in the normal OSE. OSE cells undergo apoptosis to facilitate ovulation, as demonstrated in the goat (Murdoch \& McDonnel 2002). This apoptotic process presumably 


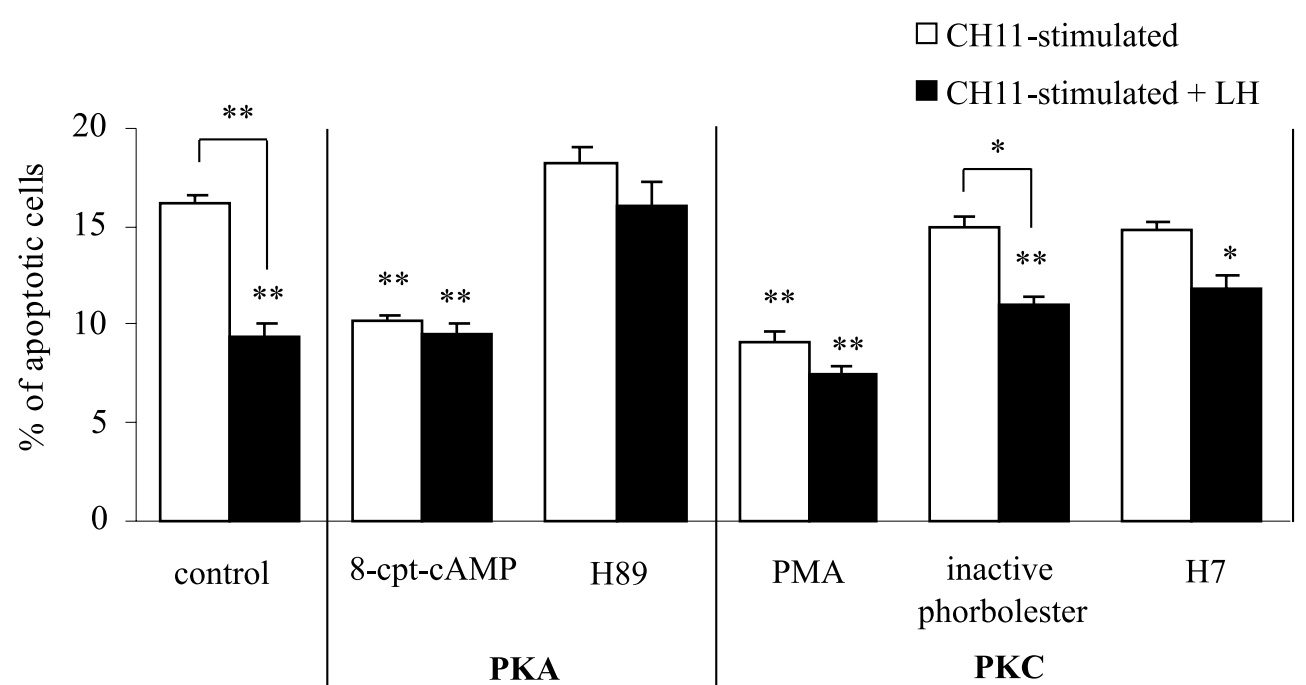

Figure 6 Effect of PKA/PKC signaling on Fas-induced apoptosis. HEY cells were treated for $8 \mathrm{~h}$ with $50 \mathrm{ng} / \mathrm{ml} \mathrm{CH} 11$ (open bars) or $50 \mathrm{ng} / \mathrm{ml} \mathrm{CH} 11$ plus $1 \mathrm{ng} / \mathrm{ml} \mathrm{LH}$ (closed bars) in the absence or presence of various compounds: $10^{-6} \mathrm{M} 8$-CPT-CAMP $(n=8), 10^{-6} \mathrm{M} \mathrm{H} 89(n=8), 10^{-6} \mathrm{M} \mathrm{PMA}(n=8), 10^{-6} \mathrm{M}$ inactive phorbolester $(n=6)$ or $10^{-6} \mathrm{M} \mathrm{H7}(n=4)$. Apoptotic indices were determined by FACS analysis and quantified as described in the legend of Fig. 4. Values represent the means \pm S.E.M. from four to eight independent experiments. Significantly different from cells treated with $\mathrm{CH} 11$ only, ${ }^{*} P<0 \cdot 01$ or ${ }^{*} P<0 \cdot 05$.

takes place via activation of the Fas pathway, as OSE cells at the ovulatory site expressed Fas, Fas ligand and active caspase-3 (Slot et al. 2006a). The Fas apoptotic machinery is also present in OSE cells at the tumor site and in OSE cells lining irregular inclusions cysts which are thought to have, under certain conditions, the capacity to develop into epithelial cancers (Scully 1995). Despite the presence of the Fas pathway, apoptotic cells were relatively scarce in OSE tumors (Slot et al. 2006b).

Fas and Fas ligand expression in HEY and Caov-3 cells are in accordance with previously published data in OSE tumor cells (Ghahremani et al. 1998, Ben Hur et al. 1999, Baldwin et al. 1999, Das et al. 2000, Munakata et al. 2000). The presence of the Fas pathway seems to reflect the ability of OSE cancer cell lines to undergo Fas-induced apoptosis. The degree of Fas-induced cell death may vary, as we found low numbers of apoptosis and immunostaining for Fas, Fas ligand and procaspase-3 in another OSE cell line, Caov-3 cells, while abundant expression of these antigens and much higher sensitivity to Fas activation were found in the HEY cell line. Dysregulation of the Fas system may contribute to ovarian tumor development and progression as has been suggested by Ghahremari and colleagues (1999). Nevertheless, the mechanism by which apoptosis is inhibited and the survival factors involved remain to be determined.

Gonadotrophins have been reported to play a major role in the regulation of ovarian apoptosis. It has been shown that follicle-stimulating hormone or the LH analog hCG suppressed the spontaneous onset of follicular DNA fragmentation in serum-free cultures of rat preovulatory follicles (Chun et al. 1994). Furthermore, treatment of hypophysectomized immature rats with follicle-stimulating hormone decreased granulosa cell apoptosis in vivo (Chun \& Hsueh 1998). Despite these observations, not much is known about the effects of gonadotrophins on OSE cell growth and/or survival. In the present study, we demonstrated that activation of Fas-induced apoptosis in the OSE cancer cell lines HEY and Caov-3 could be blocked, in part, by treatment for $12 \mathrm{~h}$ with the gonadotrophin $\mathrm{LH}$, in a relatively low concentration of $0 \cdot 1-1 \cdot 0 \mathrm{ng} / \mathrm{ml}$. In granulosa cells it has also been observed that high doses of gonadotrophic hormones, though inducing a short-lasting cAMP increase, had no inhibitory effect on apoptosis, as was found when lower doses were used (Aharoni et al. 1995). The observation that $10 \mathrm{ng} / \mathrm{ml} \mathrm{LH}$ did not inhibit Fas-induced apoptosis OSE cells may be caused by desensitization of the LH-R (Hunzicker-Dunn \& Birnbaumer 1985). Doses of $\mathrm{LH}$, in the range of $10-100 \mathrm{ng} / \mathrm{ml}$, initially causing an increase in cAMP, have been described to induce a rapid desensitization of the LH-R in different cell systems (Wang et al. 1991, Ulaner et al. 1999). A similar transient inhibitory effect on Fas-induced apoptosis was observed in response to a membrane-permeable cAMP analog, which is in line with some previous studies (Parvathenani et al. 1998, Niwa et al. 1999). cAMP might act upstream of caspase-3 activation to delay the activation of the apoptotic pathway as has been postulated in human neutrophils (Parvathenani et al. 1998, Niwa et al. 1999). Eventually, such an anti-apoptotic block may be overruled by other death signaling pathways. 
A delay in cell death as induced by LH may under certain circumstances increase the chance of survival of mutated OSE cancer cells in vivo. Moreover, it might change the ability of cancer cells to respond to chemotherapeutic agents. For example, cisplatin, which is the preferred chemotherapeutic agent for treatment of OSE cancer, has been shown to sensitize cancer cells to Fas-mediated apoptosis, by modulating several components of this apoptotic pathway. In ovarian cancer cell lines, cisplatin can upregulate Fas and Fas ligand (Uslu et al. 1996, Wakahara et al. 1997), resulting in caspase-3 activation and eventually apoptosis. Moreover, it was demonstrated that the LH homolog hCG lowered the chemosensitivity to the anticancer drug cisplatin in the OSE cancer cell line OVCAR-3 (Kuroda et al. 1998). These authors hypothesized that the hCG-induced inhibition of ciplatin-induced apoptosis was dependent on the presence of LH-Rs, as in cells lacking functionals LH-Rs, i.e. the SKOV-3 cell line, hCG failed to block cisplatin-induced cell death (Kuroda et al. 1998).

To obtain more insight in the role of LH in the inhibition of Fas-induced apoptosis in OSE cells, we have investigated whether the survival effect was indeed the result of inhibition of apoptosis or was caused by stimulation of HEY cell growth. Several studies have demonstrated that certain OSE cancer cell lines undergo enhanced cellular proliferation following $\mathrm{LH}$ addition (Casagrande et al. 1979, Simon et al. 1983, Osterholzer et al. 1985, Wimalasena et al. 1992, Syed et al. 2001, Parrott et al. 2001b). Controversy, however, exists whether LH has an influence on the proliferative activity of all OSE cells, as also decreased (Zheng et al. 2000, Tourgeman et al. 2002) or unchanged (Ala-Fossi et al. 1999, Ivarsson et al. 2001, Wright et al. 2002) OSE cell proliferation in response to $\mathrm{LH}$ have been reported. In the HEY cell line, proliferation rates as measured by the use of a BrdU-incorporation assay, were not affected following supplementation with $\mathrm{LH}$ under serum- and growth factor-free conditions. This suggests that the observed increased OSE survival was due to inhibition of apoptosis and not to a modulation of cell proliferation.

We have also analyzed the signal transduction pathway of LH in these cells. In ovarian follicular cells, it is well established that LH interacts with its cognate receptor and stimulates a $G_{s}$-protein that leads to the production of cAMP, followed by activation of PKA and subsequently induces steroid production. Interestingly, the secondmessenger molecule cAMP also modulates the apoptotic program in these cells; when follicles were treated in vitro with low doses of cAMP analogs, apoptosis was prevented (Johnson et al. 1996, Chun \& Hsueh 1998). In nonfollicular cells, cAMP and cAMP-dependent PKA have been shown to modulate apoptosis in a wide variety of ways. In human neutrophils, cAMP analogs activate PKA resulting in a delay or suppression of apoptosis induced by either tumor necrosis factor- $\alpha$ or Fas. Inhibitors of
PKA activity could antagonize the suppressive effect of cAMP on tumor necrosis factor- $\alpha$-induced apoptosis (Parvathenani et al. 1998, Niwa et al. 1999, Martin et al. 2001). In contrast, in various human cancer cells, cAMP analogs have been demonstrated to induce or accelerate apoptosis (Kim et al. 2001).

Up to now, there was no evidence for activation of PKA in OSE cancer cells, nor for regulation of PKA activity by LH in these cells. In the present study, we have demonstrated that HEY cells respond to LH with enhanced cAMP production. Moreover, we showed that a cAMP analog could mimic the anti-apoptotic effect of $\mathrm{LH}$, and that an inhibitor of PKA could reverse this effect. Previously, it has been demonstrated that the extent and the duration of the intracellular rise in cAMP might play an important role in controlling the rate and extent of apoptosis in cultured granulosa cells (Aharoni et al. 1995). In addition, very low doses of LH have been shown to elicit physiological actions in a variety of cells concomitant with barely detectable cAMP responses (Browne \& Bhalla 1991, Yong et al. 1994). A small but significant 15\% increase in cAMP levels in a lung cancer cell line was able to inhibit UV-induced apoptosis (Hastings et al. 2004). Possibly, the anti-apoptotic effect of $\mathrm{LH}$ is exerted by small increases of cAMP concentrations acting at discrete cellular locations and by activation of multiple signaling pathways in addition to PKA, such as the PKC pathway (Johnson 2003). Activation of PKC by treatment with the phorbol ester PMA has been demonstrated to block Fas-induced apoptosis in human T-cells and Jurkat cells (Rudert et al. 1997). The present study demonstrates that Fas-induced apoptosis is also blocked by PKC activation in the OSE cell line HEY. However, the PKC inhibitor $\mathrm{H} 7$ could not completely antagonize the effect of LH, implying that the anti-apoptotic effect of LH most likely does not signal predominantly through PKC.

Gonadotrophins have been suggested to play a role in the etiology of OSE cancer, as several cases have been reported of OSE cancers arising in infertile women during or after prolonged treatment with gonadotrophins. Moreover, the incidence of OSE cancer is increased in women during the years after menopause when serum gonadotrophin levels are high, i.e. within the range of 7-47 IU/1 (Miller 2004), which corresponds to approximately 1-7 $\mathrm{ng} / \mathrm{ml} \mathrm{LH}$. Hence, the transient anti-apoptotic effect of LH in OSE cancer cells as demonstrated in the present study may be relevant for future treatment of OSE. However, in order to be able to extrapolate our in vitro results to the in vivo situation further research is required.

\section{Acknowledgements}

During this investigation Jennifer Dorrington sadly passed away. This study was supported in part by a grant from the Jan Dekkerstichting and Dr Ludgardine 
Bouwmanstichting, The Netherlands. We would like to thank Dr C van de Lest and Professor W Stoorvogel (Department of Biochemistry \& Cell Biology, Utrecht University) for their support in the statistical evaluation and for reviewing this paper, respectively. The authors declare that there is no conflict of interest that would prejudice the impartiality of this scientific work.

\section{References}

Aharoni D, Dantes A, Oren M \& Amsterdam A 1995 cAMP-mediated signals as determinants for apoptosis in primary granulosa cells. Experimental Cell Research 218 271-282.

Ala-Fossi SL, Grenman S, Zhang FP, Blauer M, Punnonen R \& Maenpaa J 1999 Ovarian cancer and gonadotrophins in vitro: new evidence in favor of independence. Anticancer Research 19 4289-4295.

Anderson SM \& Dimitrievich E 1996 Ovulation induction for infertility is it safe or not? South Dakota Journal of Medicine 49 419-421.

Auersperg N, Wong AS, Choi KC, Kang SK \& Leung PC 2001 Ovarian surface epithelium: biology, endocrinology, and pathology. Endocrine Reviews 22 255-288.

Baldwin RL, Tran H \& Karlan BY 1999 Primary ovarian cancer cultures are resistant to Fas-mediated apoptosis. Gynecological Oncology 74 265-271.

Ben Hur H, Gurevich P, Huszar M, Ben Arie A, Berman V, Tendler Y, Tchanishev R, Zinder O, Mor G, Zaltsman Y et al. 1999 Apoptosis and apoptosis-related proteins in the epithelium of human ovarian tumors: immunohistochemical and morphometric studies. European Journal of Gynaecological Oncology 20 249-253.

Browne ES \& Bhalla VK 1991 Does gonadotrophin receptor complex have an amplifying role in cAMP/testosterone production in Leydig cells? Journal of Andrology 12 132-139.

Bukovsky A, Chen TT, Wimalasena J \& Caudle MR 1993 Cellular localization of luteinizing hormone receptor immunoreactivity in the ovaries of immature, gonadotrophin-primed and normal cycling rats. Biology of Reproduction 48 1367-1382.

Casagrande JT, Louie EW, Pike MC, Roy S, Ross RK \& Henderson BE 1979 'Incessant ovulation' and ovarian cancer. Lancet 2 170-173.

Chun SY \& Hsueh AJ 1998 Paracrine mechanisms of ovarian follicle apoptosis. Journal of Reproductive Immunology 39 63-75.

Chun SY, Billig H, Tilly JL, Furuta I, Tsafriri A \& Hsueh AJ 1994 Gonadotrophin suppression of apoptosis in cultured preovulatory follicles: mediatory role of endogenous insulin-like growth factor I. Endocrinology 135 1845-1853.

Cooke BA 1999 Signal transduction involving cyclic AMP-dependent and cyclic AMP-independent mechanisms in the control of steroidogenesis. Molecular and Cellular Endocrinology 151 25-35.

Cramer DW \& Welch WR 1983 Determinants of ovarian cancer risk. II. Inferences regarding pathogenesis. Journal of the National Cancer Institute 71 717-721.

Cramer DW, Hutchison GB, Welch WR, Scully RE \& Ryan KJ 1983 Determinants of ovarian cancer risk. I. Reproductive experiences and family history. Journal of the National Cancer Institute 71 711-716.

Das H, Koizumi T, Sugimoto T, Chakraborty S, Ichimura T, Hasegawa K \& Nishimura R 2000 Quantitation of Fas and Fas ligand gene expression in human ovarian, cervical and endometrial carcinomas using real-time quantitative RT-PCR. British Journal of Cancer 82 1682-1688.

Fathalla MF 1971 Incessant ovulation-a factor in ovarian neoplasia? Lancet 2163.

Foghi A, Ravandi A, Teerds KJ, Van Der DH, Kuksis A \& Dorrington J 1998 Fas-induced apoptosis in rat thecal/interstitial cells signals through sphingomyelin-ceramide pathway. Endocrinology 139 2041-2047.

Ford D, Easton DF \& Peto J 1995 Estimates of the gene frequency of BRCA1 and its contribution to breast and ovarian cancer incidence. American Journal of Human Genetics 57 1457-1462.

Ghahremani M, Foghi A \& Dorrington JH 1998 Activation of Fas ligand/receptor system kills ovarian cancer cell lines by an apoptotic mechanism. Gynecological Oncology 70 275-281.

Ghahremani M, Foghi A \& Dorrington JH 1999 Etiology of ovarian cancer: a proposed mechanism. Medical Hypotheses 52 23-26.

Guthrie HD, Garrett WM \& Cooper BS 1998 Follicle-stimulating hormone and insulin-like growth factor-I attenuate apoptosis in cultured porcine granulosa cells. Biology of Reproduction 58 390-396.

Hastings RH, Araiza F, Burton DW, Bedley M \& Deftos LJ 2004 Parathyroid hormone-related protein regulates apoptosis in lung cancer cells through protein kinase A. American Journal of Physiology Cell Physiology 287 C1616-C1622.

Hunzicker-Dunn M \& Birnbaumer L 1985 The involvement of adenylyl cyclase and cyclic AMP-dependent protein kinases in luteinizing hormone actions. In Luteinizing Hormone Action and Receptors, pp 57-134. Ed M Ascoli. Boca Raton, FL, USA: CRC Press.

Indrapichate $\mathrm{K}$, Meehan D, Lane TA, Chu SY, Rao CV, Johnson D, Chen TT \& Wimalasena J 1992 Biological actions of monoclonal luteinizing hormone/human chorionic gonadotrophin receptor antibodies. Biology of Reproduction 46 265-278.

Ivarsson K, Sundfeldt K, Brannstrom M, Hellberg P \& Janson PO 2001 Diverse effects of FSH and LH on proliferation of human ovarian surface epithelial cells. Human Reproduction 16 18-23.

Jindal SK, Ishii E, Letarte M, Vera S, Teerds KJ \& Dorrington JH 1995 Regulation of transforming growth factor alpha gene expression in an ovarian surface epithelial cell line derived from a human carcinoma. Biology of Reproduction 52 1027-1037.

Johnson AL 2003 Intracellular mechanisms regulating cell survival in ovarian follicles. Animal Reproductive Science 78 185-201.

Johnson AL, Bridgham JT, Witty JP \& Tilly JL 1996 Susceptibility of avian ovarian granulosa cells to apoptosis is dependent upon stage of follicle development and is related to endogenous levels of bcl-xlong gene expression. Endocrinology 137 2059-2066.

Kamitani T, Nguyen HP \& Yeh ET 1997 Activation-induced aggregation and processing of the human Fas antigen. Detection with cytoplasmic domain-specific antibodies. Journal of Biological Chemistry 272 22307-22314.

Kim SN, Ahn YH, Kim SG, Park SD, Cho-Chung YS \& Hong SH 2001 8-Cl-cAMP induces cell cycle-specific apoptosis in human cancer cells. International Journal of Cancer 93 33-41.

Krammer PH 1999 CD95(APO-1/Fas)-mediated apoptosis: live and let die. Advances in Immunology 71 163-210.

Kuroda H, Mandai M, Konishi I, Yura Y, Tsuruta Y, Hamid AA, Nanbu K, Matsushita K \& Mori T 1998 Human chorionic gonadotrophin (hCG) inhibits cisplatin-induced apoptosis in ovarian cancer cells: possible role of up-regulation of insulin-like growth factor-1 by hCG. International Journal of Cancer 76 571-578.

Mandai M, Konishi I, Kuroda H, Fukumoto M, Komatsu T, Yamamoto S, Nanbu K, Rao CV \& Mori T 1997 Messenger ribonucleic acid expression of $\mathrm{LH} / \mathrm{hCG}$ receptor gene in human ovarian carcinomas. European Journal of Cancer 33 1501-1507.

Martin MC, Dransfield I, Haslett C \& Rossi AG 2001 Cyclic AMP regulation of neutrophil apoptosis occurs via a novel protein kinase A-independent signaling pathway. Journal of Biological Chemistry $27645041-45050$.

Miller RK 2004 New assays for estradiol, progesterone and luteinizing hormone. Clinical Laboratories Newsletter (Department of Pathology and Laboratory Medicine) 284.

Munakata S, Enomoto T, Tsujimoto M, Otsuki Y, Miwa H, Kanno H \& Aozasa K 2000 Expressions of Fas ligand and other 
apoptosis-related genes and their prognostic significance in epithelial ovarian neoplasms. British Journal of Cancer 82 1446-1452.

Murdoch WJ \& McDonnel AC 2002 Roles of the ovarian surface epithelium in ovulation and carcinogenesis. Reproduction 123 743-750.

Niwa M, Hara A, Kanamori Y, Matsuno H, Kozawa O, Yoshimi N, Mori H \& Uematsu T 1999 Inhibition of tumor necrosis factor-alpha induced neutrophil apoptosis by cyclic AMP: involvement of caspase cascade. European Journal of Pharmacology $37159-67$.

Osterholzer HO, Streibel EJ \& Nicosia SV 1985 Growth effects of protein hormones on cultured rabbit ovarian surface epithelial cells. Biology of Reproduction 33 247-258.

Parrott JA, Doraiswamy V, Kim G, Mosher R \& Skinner MK 2001a Expression and actions of both the follicle stimulating hormone receptor and the luteinizing hormone receptor in normal ovarian surface epithelium and ovarian cancer. Molecular and Cellular Endocrinology 172 213-222.

Parrott JA, Nilsson E, Mosher R, Magrane G, Albertson D, Pinkel D, Gray JW \& Skinner MK $2001 b$ Stromal-epithelial interactions in the progression of ovarian cancer: influence and source of tumor stromal cells. Molecular and Cellular Endocrinology 175 29-39.

Parvathenani LK, Buescher ES, Chacon-Cruz E \& Beebe SJ 1998 Type I cAMP-dependent protein kinase delays apoptosis in human neutrophils at a site upstream of caspase-3. Journal of Biological Chemistry 273 6736-6743.

Rudert F, Wang Y, Lindridge E \& Watson J 1997 Apoptosis through CD95 (Fas/APO-1), but not a CD40/CD95 chimeric receptor, is inhibited by phorbol-12-myristate-13-acetate. DNA Cell Biology 16 197-205.

Scully RE 1995 Pathology of ovarian cancer precursors. Journal of Cellular Biochemistry Supplement 23 208-218.

Simon WE, Albrecht M, Hansel M, Dietel M \& Holzel F 1983 Cell lines derived from human ovarian carcinomas: growth stimulation by gonadotrophic and steroid hormones. Journal of the National Cancer Institute 70 839-845.

Slot KA, Voorendt M, de Boer-Brouwer M, van Vugt HH \& Teerds KJ 2006 astrous cycle dependent changes in expression and distribution of Fas, Fas ligand, Bcl-2, Bax, and pro- and active caspase-3 in the rat ovary. Journal of Endocrinology 188 179-192.

Slot KA, de Boer-Brouwer M, Voorendt M, Sie-Go DMDS, Ghahremani M, Donnington JH \& Teerds KJ $2006 b$ Irregularly shaped inclusion cysts display increased expression of Ki67, Fas, Fas ligand and procaspase-3, but relatively little active caspase-3. Journal of Gynecological Cancer in press.

Syed V, Ulinski G, Mok SC, Yiu GK \& Ho SM 2001 Expression of gonadotrophin receptor and growth responses to key reproductive hormones in normal and malignant human ovarian surface epithelial cells. Cancer Research 61 6768-6776.

Teerds KJ \& Dorrington JH 1995 Immunolocalization of transforming growth factor alpha and luteinizing hormone receptor in healthy and atretic follicles of the adult rat ovary. Biology of Reproduction 52 500-508.

Tilly JL 1996 The molecular basis of ovarian cell death during germ cell attrition, follicular atresia, and luteolysis. Frontiers in Bioscience $1 \mathrm{~d} 1-\mathrm{d} 11$.
Tourgeman DE, Lu JJ, Boostanfar R, Amezcua C, Felix JC \& Paulson RJ 2002 Human chorionic gonadotrophin suppresses ovarian epithelial neoplastic cell proliferation in vitro. Fertility and Sterility 78 1096-1099.

Ulaner GA, Chuang J, Lin W, Woodbury D, Myers RV \& Moyle WR 1999 Desensitization and resensitization of lutropin receptors expressed in transfected Y-1 adrenal cells. Journal of Endocrinology 163 289-297.

Uslu R, Jewett A \& Bonavida B 1996 Sensitization of human ovarian tumor cells by subtoxic CDDP to anti-fas antibody-mediated cytotoxicity and apoptosis. Gynecological Oncology 62 282-291.

Vermes I, Haanen C, Steffens-Nakken H \& Reutelingsperger C 1995 A novel assay for apoptosis. Flow cytometric detection of phosphatidylserine expression on early apoptotic cells using fluorescein labelled Annexin V. Journal of Immunological Methods 184 39-51.

Wakahara Y, Nawa A, Okamoto T, Hayakawa A, Kikkawa F, Suganama N, Wakahara F \& Tomoda Y 1997 Combination effect of anti-Fas antibody and chemotherapeutic drugs in ovarian cancer cells in vitro. Oncology 54 48-54.

Wang H, Segaloff DL \& Ascoli M 1991 Lutropin/choriogonadotrophin down-regulates its receptor by both receptor-mediated endocytosis and a cAMP-dependent reduction in receptor mRNA. Journal of Biological Chemistry 266 780-785.

Whittemore AS, Harris R \& Itnyre J 1992 Characteristics relating to ovarian cancer risk: collaborative analysis of 12 US case-control studies. IV. The pathogenesis of epithelial ovarian cancer. Collaborative Ovarian Cancer Group. American Journal of Epidemiology 136 1212-1220.

Wimalasena J, Dostal R \& Meehan D 1992 Gonadotrophins, estradiol, and growth factors regulate epithelial ovarian cancer cell growth. Gynecological Oncology 46 345-350.

Wright JW, Toth-Fejel S, Stouffer RL \& Rodland KD 2002 Proliferation of rhesus ovarian surface epithelial cells in culture: lack of mitogenic response to steroid or gonadotrophic hormones. Endocrinology 143 2198-2207.

Wu ML, Whittemore AS, Paffenbarger RS Jr, Sarles DL, Kampert JB, Grosser S, Jung DL, Ballon S, Hendrickson M \& Mohle-Boetani J 1988 Personal and environmental characteristics related to epithelial ovarian cancer. I. Reproductive and menstrual events and oral contraceptive use. American Journal of Epidemiology 128 $1216-1227$.

Yong EL, Hillier SG, Turner M, Baird DT, Ng SC, Bongso A \& Ratnam SS 1994 Differential regulation of cholesterol side-chain cleavage (P450 scc) and aromatase (P450 arom) enzyme mRNA expression by gonadotrophins and cyclic AMP in human granulosa cells. Journal of Molecular Endocrinology 12 239-249.

Zheng W, Lu JJ, Luo F, Zheng Y, Feng Y, Felix JC, Lauchlan SC \& Pike MC 2000 Ovarian epithelial tumor growth promotion by follicle-stimulating hormone and inhibition of the effect by luteinizing hormone. Gynecological Oncology 76 80-88.

Received 8 September 2005

Accepted 16 November 2005 